\title{
PENGARUH TERAPI MUROTTAL TERHADAP TINGKAT KONSENTRASI SISWA KELAS VIII. G DI MTSN 2 MUARA ENIM TAHUN 2018
}

\author{
Shinta Maharani ${ }^{(1)} \quad$ Devy Dwi Putri $^{(2)}$ \\ (1) Dosen Prodi Ilmu Keperawatan STIK Siti Khadijah Palembang \\ (2) Mahasiswa Prodi Ilmu Keperawatan STIK Siti Khadijah Palembang
}

\begin{abstract}
ABSTRAK
Salah satu tugas perkembangan anak-anak usia 11-15 tahun ialah berpikir dengan cara yang lebih abstrak dan logis serta pemikiran lebih idealis. Kemampuan berpikir ini akan menjadi terganggu apabila remaja sulit berkonsentrasi saat pembelajaran. Oleh karena itu diperlukan suatu metode yang menyenangkan dan dapat membuat anak rileks dalam belajar sehingga mereka dapat memusatkan konsentrasinya pada pembelajaran yang sedang berlangsung. Salah satu metode yang dapat digunakan adalah dengan terapi Murrotal Al-Qur'an. Tujuan penelitian adalah untuk mengetahui adakah pengaruh terapi murottal terhadap konsentrasi siswa di MTsN 2 Muara Enim. Penelitian ini menggunakan desain quasi eksperimen dengan rancangan one group pretest postest. Sampel yang digunakan adalah seluruh siswa kelas VIII.G di MTsN 2 Muara Enim. Hasil penelitian didapatkan rata-rata skor konsentrasi siswa kelas VIII.G sebelum diberikan terapi murottal adalah 10,84 dengan standar deviasi 3,043. Sedangkan rata-rata skor konsentrasi siswa kelas VIII.G setelah diberikan terapi murottal 17,90 dengan standar deviasi 1,233, sehingga didapatkan perbedaan rerata skor konsentrasi sebelum dan setelah terapi murottal yaitu 7,06 dengan standar deviasi 1,81 . Uji wilcoxon signed ranks didapatkan $\rho$ value $=0,000$, dengan nilai $\alpha=0,05(p<0,05)$, hal ini menunjukan bahwa ada perbedaan yang signifikan antara konsentrasi siswa sebelum dan setelah diberikan terapi murottal. Diharapkan pihak sekolah dapat membuat kebijakan tentang penerapan terapi murottal dalam dalam meningkatkan konsentrasi siswa.

Kata Kunci : Terapi Murottal, Konsentrasi, Remaja.
\end{abstract}

\section{THE INFLUENCE OF MUROTTAL THERAPY ON CONCENTRATION AT LEVEL VIII GRADE STUDENTS OF MTS N 2 CLASS MUARA ENIM IN 2018}

\begin{abstract}
One of the tasks of the development of children aged 11-15 years is to think in a more abstract and logical way and more idealistic thinking. This ability to think will be disrupted if teenagers have difficulty concentrating during learning. Therefore we need a method that is fun and can make children relax in learning so that they can concentrate their concentration on ongoing learning. One method that can be used is the Murrotal Al-Qur'an therapy. The aim of the study was to determine whether there was any effect of murottal therapy on the concentration of students at Muara Enim 2 MTsN. This study used a quasi-experimental design with the design of the one group pretest posttest. The sample used was all students of class VIII.G at MTSN 2 Muara Enim. The results showed that the average concentration score of class VIII.G students before Murottal therapy was given was 10.84 with a standard deviation of 3.043. While the average concentration score of class VIII.G students after being given murottal therapy was 17.90 with a standard deviation of 1.233 , so that the difference in mean concentration scores before and after murottal therapy was 7.06 with a standard deviation of 1.81 . Wilcoxon signed ranks test obtained $\rho$ value $=0,000$, with a value of $\alpha=$ $0.05(p<0.05)$, this shows that there is a significant difference between the concentration of students before and after being given murottal therapy. It is expected that the school can make a policy about the application of murottal therapy in increasing student concentration.
\end{abstract}




\section{Keywords : Murottal Therapy, Concentration, Youth.}

\section{PENDAHULUAN}

Masa remaja merupakan peralihan antara masa kanak-kanak dan masa dewasa, yang dimulai pada saat terjadinya kematangan seksual yaitu antara usia 11 atau 12 tahun sampai dengan 20 tahun yaitu menjelang masa dewasa muda (Soetjingningsih, 2008). Menurut teori perkembangan kognitif Piaget pemikiran masa remaja telah mencapai tahap pemikiran operasional formal (formal Oprational Thought), yakni suatu tahap perkembangan kognitif yang dimulai pada usia kira-kira 11 atau 12 tahun dan terus berlanjut sampai remaja mencapai masa tenang atau dewasa. Pada masa ini, anak sudah mampu memikirkan sesuatu yang akan atau mungkin terjadi, sesuatu yang abstrak.

$$
\text { Salah satu tugas }
$$

perkembangan anak-anak usia 1115 tahun ialah berpikir dengan cara yang lebih abstrak dan logis serta pemikiran lebih idealis. Kemampuan berpikir ini akan menjadi terganggu apabila remaja sulit berkonsentrasi saat pembelajaran (Setiani, 2014). Konsentrasi penuh pada siswa akan membuat siswa dapat menangkap materi yang sedang diajarkan, konsentrasi dapat membuat seseorang menguasai apa-apa yang dipelajarinya, karena dengan konsentrasi seluruh perhatian akan tertuju pada yang sedang menjadi perhatiannya. Berdasarkan penelaahan para ahli pendidikan, rendahnya kualitas prestasi belajar siswa sebagian besar disebabkan oleh lemahnya kemampuan anak didik untuk dapat melakukan konsentrasi belajar.

Konsentrasi merupakan keadaan pikiran yang diaktifkan oleh sensasi di dalam tubuh. Untuk mengaktifkan sensasi di dalam tubuh perlu keadaan yang rileks dan suasana yang tenang, karena dalam keadaan tegang seseorang tidak akan dapat menggunakan otaknya dengan maksimal karena pikiran menjadi kosong. Suasana menyenangkan berarti seseorang dalam keadaan yang rileks dan tidak ada 
ketegangan yang mengancam dirinya. Oleh karena itu diperlukan suatu metode yang menyenangkan yang membuat anak rileks dalam belajar dan dapat memusatkan konsentrasinya pada pembelajaran yang sedang berlangsung. Salah satu metode yang dapat digunakan untuk membuat anak rileks dalam belajar adalah dengan terapi Murrotal Al-Qur'an.

Berdasarkan studi pendahuluan yang peneliti lakukan di MTsN 2 Muara Enim dengan metode observasi dan wawancara dengan Wakil Kepala Sekolah bidang kesiswaan, guru dan beberapa siswa di MTs tersebut didapatkan bahwa masih banyak siswa yang sulit untuk berkonsentrasi dengan baik terutama pada kelas-kelas atas khususnya kelas VIII dan IX. Hal ini dikarenakan materi yang diajarkan mengalami peningkatan dalam tingkat kesukaran serta mata pelajaran pada kelas tersebut yang akan menjadi materi ujian nasional. Pada tahun ajaran 2017/2018 MTsN 2 Muara Enim memiliki banyak kelas, salah satunya kelas VIII yang terdiri dari 291 siswa yang terbagi menjadi 8 kelas yaitu kelas VIII.A 37 siswa, VIII.B 37 siswa, VIII.C 37 siswa, VIII.D 38 siswa, VIII.E 38 siswa, VIII.F 35 siswa, VIII.G 33 siswa, VIII.H 36 siswa. Hasil wawancara dan observasi dengan siswa-siswa kelas VIII dan pihak sekolah. Hasil wawancara dengan wali kelas VIII.G didapatkan data bahwa 15 dari 33 siswa kelas VIII.G mengalami penurunan nilai. Hasil wawancara dengan beberapa siswa kelas VIII.G, mereka menyatakan sulit untuk berkonsentrasi terhadap pembelajaran yang ada.

Berdasarkan observasi yang dilakukan, MTsN 2 Muara Enim terletak di daerah kabupaten yang penuh keramaian, MTs tersebut dekat dengan jalan utama dan terletak dekat komplek perumahan yang penuh lalu lintas kendaraan sehingga menimbulkan kebisingan yang dapat membuat suasana menjadi tidak tenang. Di sekolah ini juga belum pernah dilakukan penelitian terkait tentang murrotal dalam meningkatkan konsentrasi belajar. Peneliti ingin mengetahui "Apakah ada pengaruh pemberian terapi murrotal terhadap tingkat konsentrasi belajar siswa Kelas VIII di MTsN 2 Muara Enim ?"

\section{METODE PENELITIAN}

Jenis penelitian quasi eksperimen dengan desain one group pretest postest (One group pra-post design) yaitu penelitian yang mengungkapkan hubungan sebab akibat dengan cara melibatkan satu kelompok subyek (Notoatmodjo, 2012). 
Populasi dalam penelitian ini adalah siswa kelas VIII.G di MTsN 2 Muara Enim yang terdiri dari 33 siswa. Teknik pengambilan sampel dengan total sampling dimana jumlah sampel sama dengan jumlah populasi. Total sampel pada penelitian ini adalah 33 orang. Pengambilan data dilakukan pada tanggal 24 Juli 2018.

Instrument penelitian ini menggunakan laptop yang sudah diinstal murottal Al-Qur'an dan speaker aktif untuk terapi murottal Al-Qur'an. Digit Symbol Test digunakan untuk mengukur konsentrasi siswa.

Analisis yang digunakan dalam penelitian ini adalah analisa univariat untuk mengetahui skor konsentrasi siswa sebelum dan sesudah pemberian terapi murottal. Analisa bivariat menggunakan uji wilcoxon dengan keputusan bermakna bila nilai $p$ lebih kecil dari alpha $(\alpha=0,05)$.

\section{HASIL PENELITIAN}

Analisa Univariat

1. Skor Konsentrasi Sebelum Terapi Murottal Al-Qur'an

Tabel 4.1 Skor konsentrasi siswa kelas VIII.G sebelum dilakukan Terapi Murottal di MTsN 2 Muara Enim tahun 2018 $(n=33)$ Variabel Mean \pm

\begin{tabular}{cc}
\hline & SD \\
\hline Skor konsentrasi & $10,84 \pm$ \\
sebelum diberikan & 3,043 \\
terapi murottal & \\
\hline Hasil analisa didapatkan rata-
\end{tabular}

rata skor konsentrasi siswa kelas

VIII.G sebelum diberikan terapi

murottal adalah 10,84 dengan

standar deviasi 3,043.

2. Skor Konsentrasi Setelah Terapi Murottal Al-Qur'an

Tabel 4.2

Skor konsentrasi siswa kelas VIII.G setelah dilakukan Terapi Murottal di MTsN 2 Muara Enim tahun 2018

\begin{tabular}{cc}
\multicolumn{2}{c}{$(\mathbf{n = 3 3 )}$} \\
\hline Variabel & $\begin{array}{c}\text { Mean } \mathbf{\pm} \\
\text { SD }\end{array}$ \\
\hline Skor konsentrasi & $17,90 \pm$ \\
setelah diberikan & 1,233 \\
terapi murottal & \\
\hline
\end{tabular}

Hasil analisa didapatkan nilai rata-rata skor konsentrasi siswa kelas VIII.G setelah diberikan terapi murottal adalah 17,90 dengan standar deviasi 1,233.

Analisa Bivariat

Tabel 4.3 Hasil Uji Wilcoxon Konsentrasi Sebelum dan Setelah Terap Murottal 


\begin{tabular}{|c|c|c|c|c|}
\hline Variable & $\underset{\text { SD }}{\operatorname{Mean} \pm}$ & $\begin{array}{c}\text { Mi } \\
\mathbf{n}\end{array}$ & $\begin{array}{c}\text { Ma } \\
\mathbf{x}\end{array}$ & $\begin{array}{l}\text { pVal konsentrasi siswa kelas VIII.G } \\
\text { ue }\end{array}$ \\
\hline $\begin{array}{l}\text { Sebelum } \\
\text { diberikan } \\
\text { terapi } \\
\text { murottal }\end{array}$ & $\begin{array}{c}10,84 \pm 3 \\
043\end{array}$ & 7 & 16 & $\begin{array}{l}\text { setelah diberikan terapi murottal } \\
17,90 \text { dengan standar deviasi } \\
1,233, \text { sehingga didapatkan }\end{array}$ \\
\hline
\end{tabular}

\begin{tabular}{c|c|c|c|}
$\begin{array}{c}\text { diberikan } \\
\text { terapi } \\
\text { murottal }\end{array}$ & 233 & & \\
& & & \\
Perbedaan & & & \\
& &
\end{tabular}
perbedaan rerata skor konsentrasi sebelum dan setelah terapi Perbedaan $\quad 7,06 \pm 1,81$ murottal yaitu 7,06 dengan standar Mean+SD deviasi 1,81 . Dari hasil uji wilcoxon

Berdasarkan tabel 4.3 menunjukkan bahwa didapatkan skor minimum sebelum terapi murottal yaitu 7 dan skor maksimum 16, sedangkan skor minimum setelah terapi murottal yaitu 15 dan skor maksimum 20 . Hasil analisis dengan uji wilcoxon didapatkan nilai $p=0,000$. Hal ini dapat disimpulkan bahwa ada pengaruh terapi murottal terhadap konsentrasi siswa kelas VIII.G di MTsN 2 Muara Enim.

\section{PEMBAHASAN}

Pada hasil penelitian didapatkan rata-rata skor konsentrasi siswa kelas VIII.G sebelum diberikan terapi murottal adalah 10,84 dengan standar deviasi 3,043. Sedangkan rata-rata skor signed ranks didapatkan $\rho$ value $=$ 0,000, dengan nilai $\alpha=0,05$ $(p<0,05)$, hal ini menunjukan bahwa ada pengaruh konsentrasi siswa kelas VIII.G sebelum dan setelah diberikan terapi murottal.

Relaksasi adalah salah satu cara dalam meningkatkan konsentrasi seseorang (Surya, 2010). Nuryana dan Purwanto (2010 dalam Apriyani, 2015) menyatakan bahwa konsentrasi merupakan keadaan pikiran yang diaktifkan oleh sensasi di dalam tubuh. Sensasi tersebut dapat diaktifkan dengan keadaan yang rileks dan suasana yang tenang. Kondisi yang rileks dan suasana yang tenang dapat dicapai dengan mendengarkan murottal AlQur'an. Terapi murottal dapat meningkatkan dimensi kreatif yang identik dengan proses belajar dan 
salah satunya adalah konsentrasi (Olivia, 2010).

Heru dalam Siswatinah (2011) menyatakan bahwa terapi murottal yang diperdengarkan dengan tempo yang lambat serta harmonis dapat menurunkan hormon-hormon stress, mengaktifkan hormone endorphin alami, meningkatkan perasaan rileks, dan mengalihkan perhatian dari rasa takut, cemas serta tegang. Hormone endorphin ini bereaksi seperti morfin yaitu dapat membuat kita merasa tenang, nyaman dan rileks.

Hasil penelitian ini sejalan dengan penelitian yang dilakukan oleh Apriani (2015). Apriyani melakukan penelitian tentang pengaruh terapi murottal terhadap konsentrasi blajar siswa kelas $\mathrm{V}$ di SD Muhammadiyah 2 Pontianak dengan hasil nilai $p=0,001$. Berdasarkan data diatas dapat disimpulkan bahwa nilai $p(0,001)$ $<0,05$ yang artinya $\mathrm{Ha}$ diterima dan ada pengaruh terapi Murottal terhadap konsentrasi belajar siswa kelas $\mathrm{V}$ di SD Muhammadiyah 2 Pontianak.
Hasil penelitian ini juga sejalan dengan penelitian yang dilakukan Nuraini (2017). Nuraini melakukan penelitian tentang Pengaruh terapi audio murottal Al-Qur'an terhadap konsentrasi belajar pada pembelajaran matematika dengan hasil nilai $\quad p=(0,006)$. Berdasarkan data diatas dapat disimpulkan bahwa nilai $\mathrm{p}(0,006)$ $<0,05$ yang artinya Ha diterima dan ada pengaruh terapi audio Murottal Al-Qur'an terhadap konsentrasi belajar pada pembelajaran matematika.

Terapi Murottal merupakan suatu metode yang tepat untuk digunakan dalam meningkatkan konsentrasi siswa, utamanya konsentrasi dalam belajar. Rangsangan murottal Al-Qur'an dapat dijadikan alternative terapi relaksasi untuk individu yang mengalami kecemasan, ketegangan dan menurunnya konsentrasi.

\section{KESIMPULAN}

Berdasarkan hasil penelitian dan pembahasan pengaruh terapi Murottal terhadap konsentrasi 
siswa kelas VIII.G MTsN 2 Muara Enim, maka dapat disimpulkan sebagai berikut:

Responden dalam penelitian ini berjumlah 33 responden. Rata-rata skor konsentrasi belajar sebelum dilakukan terapi Murottal adalah 10,84 dan mengalami peningkatan menjadi 17,90. Berdasarkan hasil analisa data yang dilakukan dapat disimpulkan bahwa ada pengaruh terapi Murottal terhadap konsentrasi belajar sebelum dan sesudah yang dibuktikan dengan niai $p(0,000)<$ alpha $(0,05)$.

\section{SARAN}

1. Bagi MTsN 2 Muara Enim

Hasil penelitian ini dapat dijadikan acuan bagi pihak sekolah untuk membuat kebijakan tentang penerapan terapi murottal dalam meningkatkan konsentrasi belajar siswa di MTSN 2 Muara Enim.

2. Bagi Institusi Keperawatan Hasil penelitian ini diharapkan dapat memperkaya ilmu keperawatan dalam melakukan asuhan keperawatan khususnya terapi komplementer.

3. Bagi Peneliti

Diharapkan hasil penelitian ini dapat dijadikan sebagai bahan pembanding untuk penelitian lain terhadap konsentrasi pada anak.

\section{DAFTAR PUSTAKA}

Al-Qur'an dan Terjemahannya.

Apriyani, Y. (2015). Pengaruh Terapi Murottal Terhadap Konsentrasi Belajar Siswa Kelas V SD Muhammadiyah 2 Pontianak. Skripsi Sarjana Universitas Tanjungpura.

Anastasi, A. (2013). Psychological Testing (Fifth Edition). Amerika: Macmillan Publishing Co., Inc.

Ariwibowo, S.M. (2012). Pengaruh Lingkungan Belajar terhadap Prestasi Belajar Mahasiswa PPKn Angkatan 2008/2009 Universitas Ahmad Dahlan Semester Ganjil Tahun Akademik 2010/2011. Jurnal Citizenship, 1(2), Januari 2012.

Aviana, R. \& Hidayah, F. F. (2015). Pengaruh Tingkat Konsentrasi Belajar Siswa Terhadap Daya Pemahaman Materi pada Pembelajaran Kimia di SMA Negeri 2 Batang. Jurnal Pendidikan Sains Universitas 
Muhammadiyah Semarang, 3(1), Maret 2015.

Desmita. (2009). Psikologi

Perkembangan. Bandung:

Remaja Rosdakarya.

Djamarah. (2008). Psikologi Belajar. Jakarta: Rineka Cipta.

Hurlock. (2007). Psikologi Perkembangan: Suatu Pendekatan Sepanjang Rentang Kehidupan. Jakata: Erlangga.

Notoatmodjo, S. (2012). Metode Penelitian Kesehatan. Jakarta: Rineka Cipta.

Nugroho, C., \& Pramukantoro, J. A. (2007). Pengaruh Motivasi Belajar Mahasiswa Berdasarkan Latar Belakang Sekolah Pada Mata Kuliah Praktik Dasar Listrik dan Matematika Teknik 1 terhadap Prestasi BelajarMahasiswa S1 PTE UNESA tahun angkatan 2012. Jurnal Pendidikan Teknik Elektro, 3, 97-104.
Nuryana, A. \& Purwanto, S. (2010). Efektifitas Brain Gym dalam Meningkatkan Konsentrasi Belajar pada Anak. Jurnal Ilmiah Berlaka Psikologi, 12(1), 88-98.

Olivia, F. (2010). Mendampingi Anak Belajar. Jakarta: PT. Elex Media Computindo

Siswatinah. (2011). Pengaruh Terapi Murottal Terhadap Kecemasan Pasien Gagal Ginjal Kronik yang Dilakukan Tindakan Hemodialisa di RSUD Kraton. (Skripsi) tidak diterbitkan.

Soetjiningsih. (2008). Tumbuh Kembang Anak. Jakarta: Penerbit Buku Kedokteran EGC.

Surya, H. (2010). Jadilah Probadi yang Unggul. Jakarta: PT. Elex Komputindo. 